\title{
Sustainability and the facilities management in Malaysia
}

\author{
Asra Zaliza Asbollah ${ }^{1 a}$, Nordiana Mohd Isa² and Syahrul Nizam Kamaruzzaman² \\ ${ }^{1}$ Department of Geography, Faculty of Arts and Social Science, University of Malaya, Kuala Lumpur. Malaysia. \\ ${ }^{2}$ Department of Building Surveying, Faculty of Built Environment, University of Malaya, Kuala Lumpur. Malaysia.
}

\begin{abstract}
Facilities Management (FM) in the industry of environment involves numerous expertise, especially from the management side. Other than that, technology and finance are the other factors involved as well. One essential aspect of FM, other than the emphasis on technical operation, is its performance. In parallel, the performance does impact occupant behaviour and, at the same time, this performance does affect the environment. In short, this indicates that FM is in a key position to participate in delivering a sustainable environment for the industry of built environment. Sustainable facilities Management (SFM) is crucial because buildings consume more resources which will, in consequence, negatively impact the environment and generate large amounts of waste. This justifies the importance of sustainability under the umbrella of facilities management. However, FM is quite new in Malaysia's environment. Government agencies, such as JKR, have adopted and are practicing FM at the moment. Fortunately, there has been an increasing trend and awareness of SFM adoption. Therefore, this paper aims to understand and identify the contribution and practices of Sustainable Facilities Management (SFM) in Malaysia; focusing on the development taken in regards to SFM.
\end{abstract}

Keywords: sustainability, facilities management, Malaysia

\section{Introduction}

There are several definitions of Facility Management (FM), which are as follows. One that is commonly used is "an integrating approach to operating, maintaining, improving and adapting the buildings and infrastructure of an organisation in order to create an environment that strongly supports the primary objectives of that organisation" [1]. Before that, in 2004, the International Facility Management Association defined FM as a career that includes multiple disciplines to ensure the role of the built environment to work through the integration of people, place, process and technology. A previous study by Hamer [5] explained that FM is the process of planning, implementation, maintenance and taking into account the suitability of physical space and services for the organisation, and looking at related cost savings. Thus, in short, FM is the scope of the management of buildings and facilities, thoroughly and effectively involving the administration, finance, operation and maintenance of the building, while giving priority to the maintenance of the functionality of the building; this is to ensure that each component of the building and facilities are provided at optimum functionality based on the routine maintenance schedule drawn up.
FM is usually used in building maintenance, utility supplies, human resources management; or in other words, covering a wide range of services including real estate management, health and safety, as well as, contract management. Nevertheless, at an earlier stage, FM was seen as having poor relations with those sectors and other sectors such as architecture, engineering and construction professions. This was due to the old-fashioned sense of care-taking, cleaning, repairing and maintaining [15]. However, recently, there has been substantial investments towards organisations, usually to accommodate and support the wide range of activities of FM. FM as an integrated management approach, involving multi-disciplinary experts in ensuring the use of space, infrastructure, human resources and organisations optimised to deliver a purposeful service. Thus, it would be difficult to measure the productivity of FM. The issue of sustainability, on the other hand, is undoubtedly very broad and it is important for FM to emphasise sustainability aspects in their management. This justifies the importance of sustainability under the umbrella of facilities management.

The goal of implementing sustainability is to create transparency and cooperation [4]. Through transparency and cooperation, everyone is given full 
opportunity and are encouraged to actively participate in the decision-making process regarding development in the various stages such as planning, management and implementation. In addition, the related decision-making process must be done sincerely and transparently. The ultimate goal is to strengthen the involvement, responsibility and role of diverse groups of people based on various stages of planning, implementation, management and decision-making; and the basis for strengthening the integration of various parties is with the interest of achieving a pattern of sustainable development.

Thus, this paper is primarily concerned with that particular situation in the FM perspective. The situation in other industries or areas are obviously very different, and they may possess different priorities. For example, in tourism, maritime changes are more important than urban development. However, the reasons for sustainability are similar wherever and whatever the context is, and this paper attempted to provide some understanding of the background to the often complex issues under discussion.

\section{Sustainability}

Apparently, there are uncountable definitions of 'sustainability', each with its own emphasis and subtleties. As in the Brundtland Report [17], sustainability "meets the needs of the present without compromising the ability of future generations to meet their own needs". Basically it shows that the concept of continuity and fairness is available for present and future generations. Fairness, in other words, was explained as greater fairness within and among societies, or more appropriate levels of economic development and/or the need for more environmental protection. Later, in 1992, The Earth Summit on Environment and Development held in Rio de Janeiro resulted in the Agenda 21 Declaration which provided 27 principles that set out the ways in which countries should contribute to global sustainability. Many of these principles are of direct relevance to the use and management of urban environments and property in general.

The desire to realise the sustainability aspects, as stated by [4], is a shared responsibility that includes the State Government, non-governmental organisations (NGOs) and all the people. Together, they (referred to the group mentioned) share responsibility for the planning, managing, implementing and monitoring sustainable development; based on the goals, objectives and a clear aspiration for mutual benefit and prosperity. A comprehensive method is needed to ensure the sustainability concept is seen and approached as a framework that is based on the problem and not the effects of the problem. They continue to create ecosystems and the environment is seen as an ecosystem that contains elements of natural heritage, life support systems and natural resources; if used wisely, it will guarantee and improve overall welfare and social security. In addition, social harmony is to prioritise harmony and tolerance between people, caring for the elderly, youth, children and people with disabilities and without any distinction between genders, socio-economic differences and populations between urban and rural areas. Concern for the future includes the opinion that the current generation has while managing resources in a way that allows the retention of the management options of future generations; and development which emphasises the use of natural resources in a sustainable and focused measure of environmental protection is also needed.

In parallel, as Keeping and Shiers [7] mentioned, social and economic dimensions were among the global nature being discussed under sustainability. For example, long-term economic prosperity is said to depend on environmental sustainability. The consequences of short-term economic thinking and the reckless use of the planet's resources, such as water disputes between neighbouring nations, is alarming. Although these dimensions are mostly discussed among researchers and the public, people are still unaware of how these issues could affect the environment. As Lehtonen [10] explained, these dimensions are 'independent elements that can be treated, at least analytically, as separate from eachother' (p. 201). Thus, sustainability has moved from being an interesting but sometimes contested ideal, to becoming the acknowledged goal of much of international policy, including the climate change policy. It is no longer a question of whether any development policy should be understood in the context of sustainable development goals; it is a question of how.

Another example, the construction of the Bakum Dam in Sarawak, had a huge impact; especially on the indigenous people who had to relocate. Keong [8] also reported a total ecological destruction on 69,640 hectares of forest ecosystem which brought devastation to the environment and society. For that reason, it is important to identify the steps to achieve sustainability, and appropriate efforts must be actively engaged.

From the aspect of sustainable development, there are indicators to measure the progress. The indicators comprise of three sustainable development themes, such as: the environment, society and economy. In parallel, many communities have developed sustainability or quality of life indicators that effected the works of developers who run the development. All the indicators will normally be placed under few themes. For example, in Bristol, seven themes have direct relevance to property development: 
- Community safety

- Energy

- Environmental protection

- Housing and shelter

- Land use and development

- Transport

- Waste management

However, the existing approaches to sustainable development appears to focus on technical issues and it seems that the approach undertaken is a reactive approach; it is only implemented when there is an occurrence of a disaster. Unplanned development and the public's low attitude are among the causes that lead to environmental problems, especially in developing countries [13].

\section{Sustainability And The Facility Management In Malaysia}

In the Malaysian context, FM can be interpreted according to Noor Azman, Abdul Hakim and Buang Alias [14], as a practice to coordinate the operation of a physical nature and the human environment in an organisation, uniting the whole principle of business administration, as well as, process design and engineering matters related to science. In parallel, FM practices have great potential to grow and prosper, especially in the construction industry in Malaysia. Maimunah and Maizan [12] mentioned that the number of physical development and the undertaking of large sized developments are two factors that describe the volume of physical facilities that should be managed. It starts from the planning stage until the economic life span. Service providers involved in the management of physical facilities (specialty consultants, contractors, suppliers of materials and equipment, labour and general manager of the facility itself) can seize great opportunities that exist; particularly in terms of providing an integrated facility management (integrated) or comprehensive (total) to local organisations. Thus, it can be seen that the FM scale will be able to provide an efficient and effective service, especially in terms of cost. However, only government agencies, such as JKR, have adopted and are practicing FM at the moment, and this shows that the government has played an important role in the development of FM in Malaysia [15].

Initially, FM in Malaysia did not have a clear concept and direction. As clearly emphasised by Zakaria and Hamzah [18], this was believed to be due to the confusion and lack of understanding of the real concept of FM. One question that often arises is whether FM is part of a property management or otherwise. However, the existence of the Malaysian Association of Facility Management (MAFM), which was initially formed in 2005, helped strengthen all aspects of FM. Its major agendas is to bridge academicians with industry players on the knowledge-sharing platform by strengthening all aspects of FM, leading all activities related to FM and MAFM and establishing a valid and legal society in Malaysia [11]. Among the countries that have professional organisations which are actively developing FM in Asia would be Hong Kong Institute of Facilities Management (HKIFM) and Japan Facility Management Promotion Association (JFMA). In addition, the International Facility Management Association (IFMA) (United States) and the British Institute of Facilities Management (BIFM) are among the professional organisations that were first established.

Generally, FM activities (in the context of Malaysia) began after the completion of delivery to the owner or customer, and it covers every aspect of the performance and maintenance of buildings. The existence of three types of management system, namely, Quality Management System (EN ISO 9001: 2000), Environmental Management System (EN ISO 14001: 2004) and Security Unit and Health Management System (OHSAS 18001: 2007), has helped FM in providing the best service. This is because, by following the existing guidelines to some extent, it helped improve the performance of FM services.

With the increasing issue of climate change, sustainable facility management practices are also rapidly growing. Therefore, an increasingly important issue that FM professionals must take into account would be the surrounding environment. Environmental issues have become legislative issues in many areas, including FM. Potential environmental problems can cause numerous negative impacts, including additional costing for expensive environmental clean-up. As Elmualim et al. [2] emphasised, "Facilities managers have a great role in contributing to the reduction of the built environment impact on the environment and hence advancing the sustainability agenda across the three bottom lines of sustainability, the economic, environmental and social strands". Khalil et al. [9] added, "Regulations in Malaysia like ISO 14000 \& 14001 and EQA 1974 standards must be well established by all relevant stakeholders and publics as to make it more evident. It is recommended that in order to achieve meaningful improvement, facility managers must obtain adequate knowledge and develop appropriate concern for environmental issues". In reference, professionals in FM, in short, play a vital role in providing great performance and excellent sustainable facilities.

As noted above, the FM in Malaysia only involve the management of the physical aspects of building facilities and technical services, or in other words, 
only process or support activities. With this support image, facility management services are not positioned as strategic resources of the organisation, since there are four other organisations such as people, time, finances and technology [12]. In addition, a study by Elmualim et al. [2] showed that time constraints, lack of knowledge and lack of senior management commitments are the main obstacles for the implementation of a sustainable FM policy that is consistent and comprehensive. The continuation of the lack of understanding, focus and commitment of senior executives in appreciating the opportunities, threats and needs and direction in driving essential change is a major obstacle to sustainable FM practices. However, in addressing environmental problems and meeting the demands of sustainable development, several recommendations were outlined, and it should begin at an earlier stage of development. Among the suggestions include the involvement of public participation and the emphasis of environmental protection programs at the prefeasibility stage of development [9]. Hodges [6], beforehand, stated that in order to integrate sustainable practices with an organisation's desire for cost-effective FM, material durability should be integrated into the sustainable design process, and the facility manager acting as integrator, need to be integrated into the organisation's overall strategy. In short, in order to achieve the credibility for sustainability of FM, proper planning is significant; especially at a very early stage such as knowing the long-term costs and the methodology of managing physical assets.

\section{Conclusion}

Since sustainability issues have risen towards the top of the political agenda [16], the need for sustainable means of developing the environment has become increasingly urgent. Thus, a good understanding of development plan policy and sustainable development policy is required. In this regards, facility managers should play a major role in realising sustainability. Their roles are not only limited to managing, but also to facilitate the nation in achieving sustainability.

In fact, there is no doubt that Malaysia has achieved great success in making the country and citizens live in comfort and peace, from the aspect of the necessities of life and national development. However, despite comfort and success, the development is also a source of interference to all aspects of life and a clear example is the disturbance towards the environment. As noted above regarding sustainability, what the current generation is doing now will have an impact on future generations. Thus, the issue of sustainability must be taken seriously before it is too late. It is hoped that this paper will help the reader to better comprehend the relationship of sustainability issues.

\section{Acknowledgement}

The authors would like to thank the funding bodies of this research: the University of Malaya under FRGS Project. No. FP025-2014B.

\section{References}

1. Atkin, B. and Brooks, A. Total Facilities Management. Oxford: Blackwell Science Ltd, (2000).

2. Elmualim, A., et al. Barriers and commitment of facilities management profession to the sustainability agenda. Building and Environment, 45, 58-64, (2010).

3. Finch, E \& Zhang. Facilities management, Design and Management of Sustainable Built Environments. Springer, pp. 305-326, (2013).

4. Firdaus Al-Siddiq Fadzil and Zalina Haji Samadi. Penghasilan Model Pembangunan Mapan Untuk Komuniti Kampung Santubong, Sarawak. National Conference of Research Knowledge \& Intellect Application 2009 in Universiti Technologi MARA, Perak. Hamer, J. M. (1988). Facility Management Systems. New Jersey: Van Nostrand Reinhold, (2009).

5. Hamer, J. M. Facility Management Systems. New Jersey: Van Nostrand Reinhold, (1988).

6. Hodges, C. P. A facility manager's approach to sustainability. Journal of Facilities Management, 3(4), 312 - 324, (2005).

7. Keeping, M. \& Shiers, D. E. Sustainable Property Development: A guide to Real Estate and the Environment. Oxford: Blackwell, (2004).

8. Keong, C. Y. Dam-Induced Development and Environmental and Social Sustainability: The Bakun Industrialization Strategy Revisited. Journal of Economic Issues, 39(1), 123, (2005).

9. Khalil, N., et al. Sustainable Environment: Issues and Solutions from the Perspective of Facility Managers. Procedia Engineering, 20, 458-465, (2011).

10. Lehtonen, M. The Environmental-Social Interface of Sustainable Development: Capabilities, Social Capital, Institutions. Ecological Economics, 49(2), 199-214, (2004).

11. MAFM (Malaysian Association of Facility Management). Retrieved from http://www.mafm.org.my/store/ (2016).

12. Maimunah Sapri and Maizan Baba. Penyumberan Luar dalam Pengurusan Fasiliti. Skudai, Johor: UTM Press (2008). 
13. Martinez, E. et al. Participative democracy and local environmental issues. Journal of Ecological Economics, 12, 83 - 94, (2008).

14. Noor Azman Mohamat Nor, Abdul Hakim Mohammed and Buang Alias. Facility Management History and Evolution. International Journal of Facilities Management, 5 (1), (2014).

15. Syahrul Nizam Kamaruzzaman and Emma Marinie Ahmad Zawawi. Development of facilities management in Malaysia. Journal of Facilities Management, 8(1), 75 - 81, (2010).

16. United Nations. World Economic and Social Survey 2013: Sustainable Development Challenges. Department of Economic and Social Affairs, United Nations: New York, (2013).

17. WCED (World Commission on Environment and Development). Our Common Future. Oxford: Oxford University Press, (1987).

18. Zakaria Azman and Hamzah Saufi. Pelan Kualiti Hidup Dapat Elak Projek Hadapi Masalah: Majlis Aset Kebangsaan Mampu Tingkatkan Kecekapan Penyelenggaraan. Berita Harian, Aug 15, 2007, p. 2, (2007). 